\title{
Agriculture Sector Stock Index: Return and Risk Analysis
}

\author{
Jauhari Dwiputra Fadilaa ${ }^{1}$, Nunung Kusnadi², Amzul Rifin ${ }^{3}$ \\ ${ }^{1,2,3}$ Magister Science Agribusiness, Bogor Agricultural University (IPB), Jl. Raya Dramaga, Kampus IPB Dramaga Bogor 16151, Indonesia
}

\begin{abstract}
The global economic crisis affected world oil price to decline decline and also followed by crude palm oil (CPO) price (Fadila 2014). This event will give a bad news to the national stock market peformance, especially for agriculture sector itself. Using monthly stock returns data of agriculture stock return index, this research tried to measure the influence world oil and CPO prices against the return stock. Macroeconomic variables (interest rate, exchange rate, export tax, and money supply) were also added $t$ in order to complete the model and give some insides for goverment policies. ARCH/GARCH was applied to capture the effect of selected variables to return stock. The Results showed that the variables of exchange rate (US\$/IDR), money supply (M2) and CPO prices effect on the return stocks of agriculture index significantly and positively, The model also indicate that return stock of agriculture index had asymmetric volatility which is a good news will affect more on return stock than a bad news
\end{abstract}

Keywords: ARCH/GARCH/EGACH, banking stock, stock return, volatility risk

\section{Introduction}

Agriculture sector is very important on Indonesia economic growth. It contributes for Indonesia GDP around 10 percent and absorbs 30 percent of all Indonesia's labor in 2014 (agriculture ministry of Indonesia 2015). Base on that fact, goverment and other stakeholders need to mantain that sector performance. One of the strategy is improving the investment on that sector so the sector can reach the optimal level of production. Stock market becomes an option to do that. Through stock market mechanism, the sector can get enough capital to improve their business as they are expecting.

According to that situation stakeholder, not only for company but also for investor, need to know what risk they will face from this sector. In theories the more Indonesian people utilizing the stock market for investing on agriculture sector, the more profits that the sector could obtain. The increasing profit will boost the stock returns of companies. This stock return will be an indicator for investor to pick their portofolio to invest. Stock return was calculated by decreasing stock price with the previous price (t-1) in Ln condition. Moreover, all the stakeholders need to know what risk will face in the future, escpecially for the uncertainty of macroenomy fluctuation. Therefore, this research objective to measure the effect of macroenomy variabel to return stock of CPO company that listed on Jakarta Stock Exchange (JKSE).

\section{Literature Review}

The study of the sector in the international capital markets is important for stakeholders in defining their action to avoid loss. Various studies have been done to analyze relationship of macroeconomy variables against a stock markets (Asteriou and Price 2000, Antonios 2010, Khodaprasti 2014). Moreover, the crisis on Europe and US makes economic more uncertain and causes commodities price more volatile (Yong dan Lei 2011). Abdalla (2013) by VARGARCH modeling shows that rising oil prices will increase the joint-stock return Saudi Arabia (TASI). Then, a research was conducted by Phan et al. (2015) show that rise in oil prices had a positive impact on stock returns of oil-producing countries, in other hand a stock return of net imported country had an negative impact.

One simple approach had been done by using analysis of variance (ANOVA) (Khodaprasti 2014). The researcher measures the effect of exchange rates, inflation, industrial index, money supply (M1) of the stock market index in Iran. The results obtained show that all the variable significant positive effect. Further studies on macroeconomic variables found to be related to capital markets asymmetrically (Dirga 2015, Ono 2011, Abdalla and Winker 2012). The approach distinguishes the effect based on changes in the price of oil goes up or down on stock prices. The study results showed that response to rising oil prices provide a greater effect on stock price changes compared to the decline in oil prices.

\section{Data}

The stock price of agriculture sector was taken from investing.com in monthly data from January of 2011 to December of 2015. Then, the datas was calculated to get the return stock of that sector. The independent variabeles are exchange rate of rupiah (ER), interest rate (IR), and money supply (M2) which were taken from Bank of Indonesia official website. The CPO (P_CPO) and crude oil (P_OIL) price were taken from world $\bar{b}$ ank pink sheet. Then export tax (X6) variable was taken from Indonesia Taxation Authority website.

\section{Methodology}

This research is conducted through three steps: 1) Preestimation test; 2) Model estimation and selection of the best model; 3) Model evaluation or interpretation. The first step consists of four initial tests, which are stationary test, and heteroscedasticity test using the ARCH effect test. The main stage in this study is estimating the model (the second stage), which will be explained profoundly. Model evaluation stage comprises correlogram Q-stat, correlogram squared residuals, normality test, and $\mathrm{ARCH}$ LM test. 


\section{International Journal of Science and Research (IJSR) \\ ISSN (Online): 2319-7064}

Index Copernicus Value (2015): 78.96 | Impact Factor (2015): 6.391

Two methods used in the model estimation stage are ordinary least squares and variations of ARCH/GARCH using a combination of order- 0 to 3 . Among those models, the best model is selected using the Akaike Information Criterion (AIC), Schwartz Information Criterion (SC) and Hannan-Quinn Criterion (HQ). The best model is the one which has the lowest value of AIC, SC, and HQ. After obtaining the best model based on those variations, the best model is tested with the Threshold GARCH model and Exponential GARCH (TGARCH and EGARCH) to find out whether the asymmetric volatility exists in financial sector stock market.

The equation below is a mean equation used to modelize the return and variance equation used to modelize the volatility risk. The estimation method of ordinary least squares only uses mean equation, whereas the $\mathrm{ARCH} / \mathrm{ARCH}$ variation method modelize mean and variance equation simultaneously (Bollerslev 1986).

$r_{\mathrm{t}}=a_{\mathrm{t}}+b_{E R} E R_{\mathrm{t}}+b_{I R} I R_{\mathrm{t}}+b_{M Z^{2}} M 2_{\mathrm{t}}+b_{P_{-} C P O} P_{-} C P O_{\mathrm{t}}+b_{P_{-} O n} P_{-} O I$ $\sigma_{t}^{2}=\alpha_{0}+\sum_{i=1}^{4} \alpha_{i} e_{t-i}^{2}+\sum_{i=1}^{p} \beta_{i} \sigma_{t-1}^{2}$

The eight hypotheses used in this study are as follows :

H1 The depreciation of Indonesia exchange rate (US\$/IDR) affects the return of agriculture stock index $\left(b_{1}>0\right)$ positvely.

H2 The rise of interest rate negatively affects the return of financial sector stock index $\left(b_{2}<0\right)$.

H3 Money supply affects the return of financial sector stock index $\left(b_{3}<0\right)$ positively.

H4 The rise of crude palm oil price affects the return of financial sector stock index $\left(b_{4}>0\right)$ positively.

H5 The rise of crude oil world price affects the return of financial sector stock index $\left(b_{5}<0\right)$ negatively.

H6 Export tax negatively affects the return of financial sector stock index $\left(b_{6}<0\right)$.

\section{Empirical Result}

First the data which was used need to be passed from linear regression requirements. To do that, researcher runs stationarity and heteroskedasticity test. After that, the model will be ran and chose base on the best model which is AIC, $\mathrm{SC}$, dan ARCH effect condition. As we can see the summary in table 1 below

Table 1: The result of pre-estimation tests

\begin{tabular}{|c|c|c|}
\hline Pre-estimation tests & Probability & Information \\
\hline Stationarity & 0.0000 & Stasionary \\
\hline Autocorrelation & 0.0182 & Autocorrelation exists \\
\hline ARCH effect (lag 3) & 0.8013 & ARCH effect does not exist \\
\hline
\end{tabular}

The choosen model is EGARCH $(2,3)$ which has the least AIC and SC, no arch effect. So the model that choosen can be concluded in equation form below.

$r_{\mathrm{t}}=-3.29+0.14^{*} E R_{\mathrm{t}}+0.44 I R_{\mathrm{t}}+0.05^{*} \mathrm{M} 2_{\mathrm{t}}+0.18^{*}$

$P_{-} C P O_{t}-0.007 P_{-} O I L_{t}-0.002 X 6_{t}$ $\log \left(\sigma_{t}^{2}\right)=-5.85+0.73\left|\frac{\epsilon_{r-1}}{\sigma_{t-1}}\right|+1.38^{*}\left|\frac{\epsilon_{r-2}}{\sigma_{r-2}}\right|+0.53^{*} \frac{\epsilon_{t-1}}{\sigma_{t-1}}-$
$0.15 \log \left(\sigma_{t-1}^{2}\right)+0.20 \log \left(\sigma_{t-2}^{2}\right)+0.6 \log \left(\sigma_{t-3}^{2}\right)$

Information: The variable is significant at a critical value of ${ }^{*} 5 \%$

According from the mean equation above that the return stock of agriculture index was significanly effected from exchange rates, money supply $(\mathrm{m} 2)$, and the world price of CPO. Firstly, we discuss about exchange rate variables. The depression of Indonesia currency (rupiah) to US dollar will effect the return stock of agriculture positively. If rupiah gets 1 percent depression, it will cause the ruturn stock of agriculture increase by 0.1366 percent. Another research (Joseph 2002) shows similar result that national currency depression will cause positive effect on sector that having export orientation. Beacuse the rise of price will lead the expected return of sector to $t$. The depression of national currency is making export price product "looks" cheaper. So the demand of that product will rise and make more profit to that sector. Therefor, investor will react postively to this condition by the increasing confidence of it.

Secondly, money supply (M2) has positve effect on return stock on agriculture index on Indonesia. The increasing of M2 stimulates economic growth, so does the investment. The increasing one percent of national money supply (M2) will also increase of return stock of agriculture index. This result is also consistent of another research, such as (Khodraspati 2014).

Thirdly, the world prcie of CPO cause positive effect on return stock significanly. The increasing of CPO price, in ceteris paribus condition, will also lead profit of the sector goes up. This condition is making investor confidence increase. So the investment demand of this sector will also up and return stock finally increase. Moreover, the tax variabel (X6) shows a negative relation to return stock of agriculture. But that variable is statistically not significant, so it conclude that Indonesia's goverment tax policy of agriculture sector is relatively good.

Base on the result of $\operatorname{EGARCH}(2,3)$ which was applied to this research, it showed that return stock of agrculture index has asymmetric volatility. If a good news happen it will give more impact on return stock than a bad news. This is a signal for investors to invest in financial sector stock market because positive sentiment (good news) will generate higher value of return compared to the declining value of return when negative sentiment (bad news) happens.

\section{Conclusion}

The stock market of agriculture sector should be utilized to improve the investment of agriculture business in Indonesia. Therefore, all stakeholders need to know what risk they will face from investing in this sector, especially about macroenomy uncertainty fluctuation. The research that had been done shows exchange rate, money supply, and crude palm oil price are significantly effect stock return on agriculture sector. By the increasing of money supply and crude palm oil price, return stock of agriculture sector will 


\section{International Journal of Science and Research (IJSR) \\ ISSN (Online): 2319-7064 \\ Index Copernicus Value (2015): 78.96 | Impact Factor (2015): 6.391}

also increase. Then, if exhchange rate of Indonesia is to depreciate, the return stock will increase. In general, the model that was used show an asymmetric volatility. The good news on this sector will lead more impact than a bad news. Many possibilities are still open to analyze other macroeconomy variables effect on return stock of agriculture sector. Because economic theory does not state which factors or how many factors that should be used to measure a return stock movement, on this case. Moreover, measuring internal factors of agriculture sector could be an usefull additional variable to complete the return stock model.

\section{References}

[1] Abdalla Suliman Zakaria S, Peter Winker. 2012. Modelling stock market volatility using univariate GARCH models: evidence from Sudan and Egypt. International journal of economics and finance. Vol. 4, no 8,2012

[2] Abdalla Suliman Zakaria S. 2013. Modelling the impact of oil price fluctuation on the stock returns in an emerging market: The case of Saudi Arabia. Interdisciplinary journal of research in business. Vol 2, issue 10, pp. 10-20

[3] Asteriou D, S Prince. 2000. Financial development and economic growth: time series evidence for the case of U.K. The journal of Cyprus economic society. Vol. 4, pp. 122-141

[4] Bollersev, Tim. 1986. Gerneralized Autoregressive Conditional Heteroskedasticity. Journal of econometrics 31 (1986) 307-327. North Holland

[5] Dirga, Satria Prawira. 2015. Analisis pengaruh variabel makroekonomi terhadap return kelompok saham sektor perkebunan. Bogor [ID]: Institut Pertanian Bogor

[6] Fadila, Jauhari Dwiputra. 2014. Pengaruh pergerakan harga minyak dunia terhadap harga kedelai dan CPO. Bogor [ID]: Institut Pertanian Bogor

[7] Joseph, N., (2002), Modelling the Impacts of Interest Rate and Exchange Rate Changes on UK Stock Returns. Derivatives Use, Trading \& Regulation, 7(4), 306-323.

[8] Khodaparasti RB. 2014. The role of macroeconomic variables in the stock market in Iran. Polish journal of management studies. Vol 10, no .2

[9] Ono Shigeki. 2011. Oil price shocks and stock market in BRICs. The European journal of comparative economics. Vol. 8, n. 1, pp. 29-45

[10] Phan DHB, S.S Sharma, P.K Narayan. 2015. Oil price and stock returns of consumers and producers of crude oil. Financial econometrics series SWP 2015/12

\section{Author Profile}

Jauhari dwiputra fadila is a student in magister science of Agribusiness in Institut Pertanian Bogor who's finishing his final paper for the requirement of the study. I entered IPB since 2010 as bachelor student and graduated in 2014. After that I took master program in IPB in 2014 and also took Agribusiness as the major. 